\title{
Nation Branding: Dampak Kehadiran Pemimpin Politik di Platform Media Sosial
}

\author{
Febby Amelia Trisakti ${ }^{1}$, Hifni Alifahmi ${ }^{2}$ \\ ${ }^{1}$ Universitas Islam Negeri Sultan Syarif Kasim Riau \\ ${ }^{2}$ Universitas Indonesia \\ email: febbytrisakti@gmail.com
}

\begin{abstract}
Nation branding in the digital era is marked by the presence of competing countries to gain world recognition by significantly promoting their norms, values, ideas, tourism and investment opportunities, through the use of online social media platforms and influencers. The focus of this research is to measure the impact of President Jokowi's presence on a digital platform on the development of a nation brand. The focus platform is Twitter as the main channel for the government to strengthen the country's brand equity. This study aims to examine aspects of nation branding displayed through social media content Twitter national leaders, the President of the Republic of Indonesia, Joko Widodo. The results of this study revealed that the reaction to the President's presence on social media was very minimal in terms of projecting the country's values, because people were more focused on discussing "light" and "informal" topics. Therefore, tourism content highlighted on Twitter needs to increase speed in 3A: Accessibility (Transportation), Amity (facilities), and Attractions at a tourist destination (Reputation Performance), a relaxed state that is not directly related to tourism (Symbolic Reputation).
\end{abstract}

Keywords: Nation Branding, Social Media, Key Opinion Leader

\begin{abstract}
Abstrak: Nation branding di era digital ditandai dengan kehadiran negara-negara yang bersaing untuk mendapatkan pengakuan dunia dengan mempromosikan norma, nilai, ide, pariwisata dan peluang investasi mereka secara signifikan, melalui penggunaan platform media sosial dan influencer daring. Fokus penelitian ini adalah mengukur dampak kehadiran Presiden Jokowi pada platform digital terhadap pembangunan nation brand. Platform yang menjadi fokus adalah Twitter sebagai saluran utama bagi pemerintah untuk memperkuat ekuitas merek negara. Penelitian ini bertujuan untuk mengkaji aspek nation branding yang ditampilkan melalui konten media sosial Twitter pemimpin bangsa, yakni Presiden Republik Indonesia, Joko Widodo. Hasil penelitian ini mengungkapkan bahwa reaksi terhadap kehadiran Presiden di media sosial sangat minim dalam hal memproyeksikan nilai-nilai negara, karena orang-orang lebih fokus membahas topik "ringan" dan "informal". Oleh karena itu, konten pariwisata yang ditonjolkan pada Twitter perlu meningkatkan kecepatan dalam 3A: Aksesibilitas (transportasi), Amenitas (fasilitas), dan Atraksi di tujuan wisata (Kinerja Reputasi), keadaan santai yang tidak terkait langsung dengan pariwisata (Reputasi Simbolik).
\end{abstract}

Kata kunci: Nation Branding, Media Sosial, Key Opinion Leader

\section{Pendahuluan}

Indonesia sejak dahulu telah dikenal sebagai negara dengan sumber daya alam berbasis pertanian dan maritim, yang telah sering memikat negara lain untuk mengunjungi negara tersebut. Seiring berjalannya waktu, merek negara Indonesia telah bergeser dari pengaruh agraris pada pengaruh yang lebih politis. Sejak 2014, Indonesia telah berupaya memperbarui mereknya dengan berfokus pada pesan tunggal dan strategi komunikasi terfokus melalui 
sektor pariwisata, dengan kampanye "Wonderful Indonesia" atau "Pesona Indonesia". Pesan untuk kedua kampanye ini adalah sama, tetapi nama itu sendiri tersegmentasi untuk target audiens asing dengan yang pertama dan target audiens lokal dengan yang kedua. Konsep Wonderful Indonesia adalah pengenalan warisan yang kaya dan beragam di Indonesia, yang meliputi alam, simbolisme, seni kuliner, inovasi artistik dan budaya. Ini kemudian digunakan sebagai jembatan menuju diplomasi internasional. Indonesia telah menggunakan budaya mereka sendiri untuk meningkatkan kepentingan masyarakat internasional terhadap kekayaan alam dan budaya Nusantara. Tiga kategori utama merek bangsa adalah: budaya, alam dan karya kreatif. (Al Hafiz, 2017)

Mengingat persepsi global tentang Indonesia, pada tanggal 27 September 2016 dalam sebuah pertemuan yang disebut oleh Presiden Jokowi, dinyatakan bahwa sebuah negara besar seperti Indonesia harus memiliki citra positif dan reputasi di seluruh dunia. (Setkab, 2016) Citra positif tidak hanya akan memperkuat identitas negara tetapi juga menanamkan kebanggaan dalam bangsa dan menunjukkan keunggulan kompetitif memiliki lebih dari negara lain. Presiden memerintahkan semua Kementerian untuk memiliki pesan tunggal yang berkaitan dengan branding bangsa dan fokus pada menyoroti pesan kunci dari: Pariwisata, investasi dan perdagangan. Presiden Jokowi, selama forum, menyimpulkan bahwa titik masalah utama adalah kurangnya sinkronisitas dalam kampanye, dengan berbagai Kementerian menjalankan tagline yang berbeda yang berbeda-beda dari kampanye utama dan objektif. Sun (2009) menunjukkan bahwa branding bangsa dibangun atas dasar persepsi, yang terbentuk dan didefinisikan oleh mereka di luar negeri. Stereotip umum, berita media dan pengalaman pribadi mempengaruhi persepsi. (Lumanauw, 2017)

Kampanye Wonderful Indonesia menggunakan strategi 3C yang dibuat oleh AnholtGFK Roper: kontribusi (Contribution), kompetensi (Competition) dan komunikasi (Communication). Kontribusi global didefinisikan sebagai jumlah kontribusi yang diberikan negara kepada konsumen global, hal ini menggabungkan aspek ilmu pengetahuan, budaya, dampak pada perdamaian dan keamanan dunia, keberlanjutan lingkungan yang diinginkan dan posisi pada kesejahteraan umum. Kompetensi Nasional mengacu pada segala sesuatu yang dimiliki oleh negara, dalam hal ini, Indonesia. Komunikasi Global didefinisikan oleh bagaimana konsep, strategi dan keyakinan dikomunikasikan kepada audiens di tingkat global dan lokal.

Pada 2015, kampanye Wonderful Indonesia naik lebih dari 100 peringkat poin ke 47, di mana di 2013 itu bahkan tidak termasuk di atas 140. Posisi baru Indonesia juga mengalahkan negara tetangga seperti Thailand (Ranking 83), Malaysia (Ranking 96), Hong Kong (Ranking 51) dan Korea (Ranking 60). Selain itu, Menpar Arief Yahya menjelaskan kampanye Wonderful Indonesia meraih 46 penghargaan berbeda dari 22 negara yang berbeda. (Kurniawan, 2017) Upaya branding bangsa dianggap sebagai investasi. Ketika ada 10\% peningkatan merek bangsa, ada dampak pada daerah lain. Untuk Indonesia, peningkatan ini menghasilkan pertumbuhan $11 \%$ untuk industri pariwisata dan $2 \%$ pertumbuhan investasi. Formula yang disediakan oleh The Reputation Institute menemukan korelasi yang kuat antara reputasi suatu negara dan keinginan orang untuk mengunjunginya. (Al Hafiz, 2017) 
Dalam era digital kini, upaya dalam branding bangsa dicirikan oleh adanya berbagai negara yang berlomba-lomba untuk mempromosikan norma, nilai, ide dan pariwisata mereka sendiri. Ini semua hadir peluang investasi yang signifikan dan biaya ketika memanfaatkan platform media sosial dan influencer di medium daring. Para pemimpin menyadari bahwa citra sebuah negara dibangun di atas persepsi warga internasional dan pemangku kepentingan lokal. (Kurniawan, 2017) World Tourism Organization (WHO) menjelaskan praktik nation branding dan negara berhubungan dengan manifestasi spesifik dari negara dan apa yang mewakili. (World Tourism Organization, 2002) Dalam hal ini, hubungan antara tipologi merek dari diplomasi publik dan hubungan internasional lebih jelas daripada "tempat merek" lainnya. Dengan demikian, dampak memproyeksikan citra merek yang positif kepada khalayak internasional setara dengan Kedutaan nasional, yang memiliki tujuan serupa melalui kebijakan diplomasi atau hubungan internasional. Branding bangsa memiliki teknik yang sama dalam hal tingkat representasi dan kemauan untuk mengintegrasikan aset teritorial suatu negara atau bangsa.

Umumnya, nation brand dipahami sebagai identitas nasional negara yang telah disintesis dan dipamerkan kepada khalayak global untuk membangun citra positif negara untuk tujuan mendapatkan pengakuan internasional (Delorie, 2000). Sebuah brand negara berisi konstruksi simbolis yang menekankan positif, menarik, mudah diingat, unik dan relevan kualitas suatu negara (Allan, 2004). Sebagai sebuah negara yang berusaha menciptakan sebuah merek, Indonesia perlu memamerkan karakter yang unik, yang khas dan representatif bagi negara bangsa sehingga dapat diketahui dan dikenang khalayak internasional.

Simon Anholt (2007), seorang ahli branding negara menyatakan enam saluran yang dapat mempengaruhi reputasi dan upaya branding suatu negara melalui "Hexagon" Identitas Kompetitif yakni: (1) Pariwisata, promosi langsung yang berkaitan dengan citra bangsa, serta menunjukkan pengalaman tangan pertama dari masyarakat yang mengunjungi negara sebagai wisatawan atau pelancong bisnis. Ini sering kali menjadi disuarakan paling keras dalam "branding" negara, karena Dewan Pariwisata biasanya memiliki anggaran terbesar dan pemasar yang paling kompeten; (2) Merek, yang bertindak sebagai duta kuat dari citra negara di luar negeri, tetapi hanya jika negara asalnya eksplisit. Ketika asal jelas diidentifikasi, seperti Mercedes (Made in Germany) atau Sony (Made in Japan), dampaknya dapat sama kuat sebagai kampanye pariwisata; (3) Kebijakan pemerintah, apakah itu kebijakan luar negeri yang secara langsung mempengaruhi penduduk di luar negeri, atau kebijakan domestik yang diberitakan pada media internasional; (4) Investasi, cara negara mendorong investasi batin, perekrutan orang berbakat dan mahasiswa asing, serta ekspansi ke negara oleh perusahaan asing; (5) Budaya, melalui pertukaran budaya, kegiatan budaya dan ekspor: tur dunia oleh tim olahraga, rekaman musisi terkenal, penyair, penulis atau pembuat film; (6) Orang, penduduk di negara itu sendiri: pemimpin kelas tinggi, media dan bintang olahraga, serta populasi pada umumnya; bagaimana mereka berperilaku ketika mereka berada di luar negeri dan bagaimana mereka memperlakukan pengunjung ke negara mereka. 


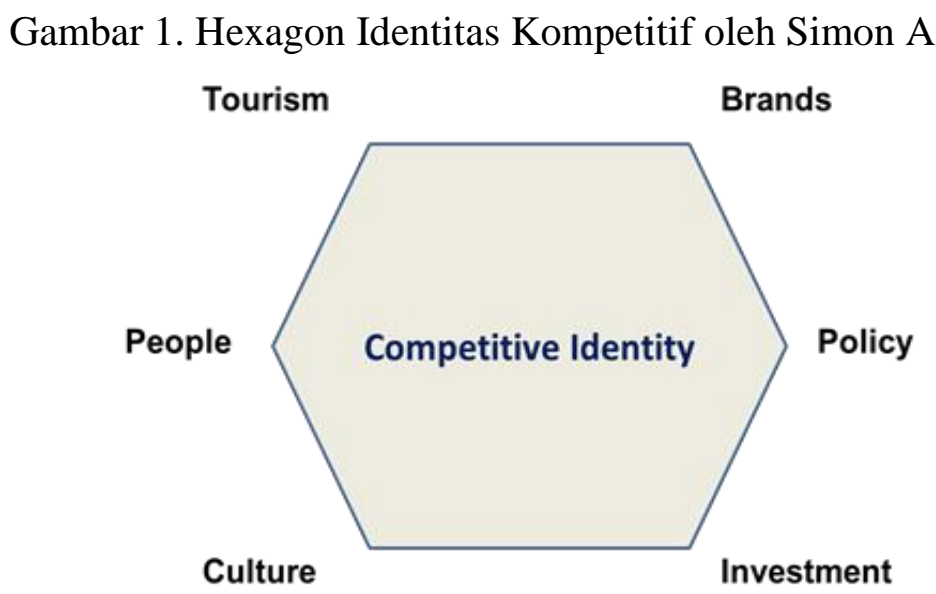

Sumber: Competitive Identity: The New Brand Management For Nations, Cities and Regions, Simon Anholt (2007)

Pesan utama yang harus diambil dari Anholt (2011) adalah bahwa jika sebuah negara ingin membangun citra internasional yang kuat, kata negara harus fokus pada pengembangan produk-produknya \& orang dan pasar mereka dengan baik, daripada hanya mengejar nama, simbol dan desain yang membentuk negara. Tidak ada jalan pintas untuk membentuk persepsi internasional dari suatu bangsa, terutama dengan enam aspek dari gambar 1, tetapi masing-masing segi harus konsisten berkoordinasi satu sama lain untuk menampilkan dan mewujudkan ide-gagasan yang relevan yang relevan dengan pengembangan produk dan perumusan kebijakan, yang secara bertahap akan secara otomatis meningkatkan reputasi suatu negara.

Anholt (2010) meringkas proses menjadi tiga komponen utama: strategi, substansi dan simbolisasi. Strategi ini adalah untuk mendefinisikan identitas bangsa dan menempatkannya di posisi yang tepat. Namun, ini akan sulit jika tidak ada segmentasi yang memungkinkan untuk dimasukkannya berbagai kebutuhan dan keinginan dari sektor pemerintah yang berbeda. Substansi adalah bagaimana mengeksekusi strategi dalam kaitannya dengan enam elemen dari: ekspor (ekonomi), pemerintah (hukum dan politik), budaya (sosial, budaya, pendidikan baru), investasi dan pariwisata; masing-masing akan membantu untuk kemajuan posisi yang diinginkan dari merek suatu negara. Tindakan simbolik dapat berupa struktur inovatif, undang-undang, reformasi investasi, dan kebijakan yang layak diberitakan yang mengejutkan publik interasional atau dipandang sebagai gerakan dramatis, seperti pemerintah Estonia yang menyatakan akses Internet sebagai hak asasi manusia, Spanyol melegalkan pernikahan sesama jenis, atau Bhutan, yang memaksakan denda mahal pada penghancuran warisan budaya sebagai bentuk menghormati budaya. Merek bangsa menurut Sun (2009) digambarkan sebagai gambar dan reputasi suatu bangsa berdasarkan persepsi yang ditetapkan dan didefinisikan oleh orang-orang di luar negeri; Persepsi mereka umumnya dipengaruhi oleh stereotip, liputan media, serta pengalaman pribadi.

Pada fokus penelitian ini, penggunaan media baru menjadi sangat penting dalam penyebaran informasi dan pesan yang telah disusun untuk calon wisatawan. McQuail menyebutkan media baru adalah media telematika, yakni perangkat teknologi elektronik yang 
berbeda dengan penggunaan yang berbeda. Sementara itu, Martin Lister dkk (2009) di New Media: A Critical Introduction menyatakan bahwa terminologi media baru mengacu pada perubahan skala besar dalam produksi media, distribusi media dan penggunaan media yang teknologi, tekstual, konvensional dan budaya. Media sosial adalah sebuah media online di mana pengguna dapat dengan mudah berpartisipasi, berbagi, dan menciptakan konten termasuk blog, jaringan sosial, wiki, forum dan dunia maya. Andreas Kaplan dan Michael Haenlein mendefinisikan media sosial sebagai "sebuah aplikasi berbasis Internet kelompok yang dibangun di atas fondasi ideologi dan teknologi web 2.0, dan yang memungkinkan penciptaan dan pertukaran konten yang dihasilkan pengguna". Media sosial merupakan tempat untuk berkumpul secara bebas, bebas dimaksudkan bebas dalam aspirasi atau hal lain yang masih bertanggungjawab, media sosial juga dapat ditafsirkan sebagai media online dimana para penggunanya dapat dengan mudah berpartisipasi dan berbagi.

Perbedaan penelitian ini dengan kajian-kajian sebelumnya pada topik yang sama adalah pada pemilihan objek yang berbeda pandangan dan menganalisa dari sudut pandang citra pemimpin serta bagaimana ia dilihat oleh masyarakat melalui platform media sosial. Konsep nation branding digunakan sebagai pisau analisis yang akan mengeksplorasi variabel yang muncul dan dimensi merek bangsa diproyeksikan melalui akun media sosial dari seorang pemimpin negara. Objek yang sama juga digunakan oleh Buarque (2015) yang menyediakan analisis melalui liputan media konvensional. Studi ini membedah citra internasional yang diproyeksikan oleh Brasil, pada liputan media asing selama dua Piala Dunia yang diadakan di negara itu, sebagai titik pendorong untuk branding dan identitas bangsa. Brasil memilih menjadi tuan rumah Piala Dunia FIFA pada 1950 dan 2014 untuk meningkatkan citra internasionalnya. Para peneliti menggunakan peristiwa ini untuk menganalisis pengaruh internasional pada pencitraan negara untuk momen bersejarah. Berbeda dengan penelitian oleh Ginesta \& Jordi (2014) yang membahas penggunaan Sepakbola sebagai bagian dari strategi branding negara bagian Qatar, penelitian ini hanya berfokus pada konten media sosial Presiden Joko Widodo. Jaringan digital telah merasuki hampir setiap aspek kehidupan kita, termasuk cara kita membangun dan memelihara hubungan dengan orang lain. Misalnya, laporan terbaru menunjukkan bahwa semakin banyak orang yang beralih ke Web untuk tetap berhubungan dengan teman dan kenalan. (Seo, 2013)

Penggunaan media sosial dijadikan alat branding bangsa yang memiliki tujuan untuk mempromosikan citra positif negara, bangsa dan rakyat, membangun identitas negara, meningkatkan pariwisata, meningkatkan ekspor dan meningkatkan investasi langsung asing. (Anholt, 2003; Dinnine, 2008; Dzenovska, 2005; Florek \& Conejo, 2006; Ostapenko, 2010). Namun, geografi negara, sejarah masa lalu, kepemimpinan, dampak budaya seperti seni dan musik, produk bermerek, stereops juga memiliki dampak yang signifikan pada citra nasional ((Seo, 2013); (Papadopoulos \& Heslop, 2002)). Sementara aktif berkomunikasi dan mendorong kampanye ini, Jokowi kehadiran di media sosial mengundang berbagai pendapat publik. Hal ini menimbulkan pertanyaan "Apakah kehadiran pemimpin nasional di platform media sosial memiliki dampak positif atau negatif pada merek suatu negara?" Sehingga, penelitian ini bertujuan untuk mengkaji aspek nation branding yang ditampilkan melalui 
konten media sosial Twitter pemimpin bangsa, yakni Presiden Republik Indonesia, Joko Widodo.

\section{Metode}

Pendekatan yang digunakan dalam studi ini adalah metode kualitatif, yang memungkinkan untuk mengumpulkan informasi yang kaya dan rinci tentang individu. Metode ini memungkinkan peningkatan kedalaman pemahaman kasus dan situasi tanpa generalisasi (Patton, 2002). Dalam studi ini, peneliti melakukan analisis konten dari akun media sosial Jokowi. Data dari media Twitter ini dikumpulkan mulai dari SeptemberDesember 2017. Kemudian juga dengan mempelajari literatur akademis tentang karya penelitian yang berkaitan dengan pencitraan merek negara. Peneliti juga mengumpulkan data yang terkandung dalam media cetak dan online pada topik branding negara Indonesia.

Menurut Berelson \& Kerlinger dalam Kriyantono (2012), analisis konten adalah metode untuk mempelajari dan menganalisis aspek inti dan tujuan dari pesan komunikasi. Dalam referensi untuk Budd, Thorp \& Denehew (1967), analisis konten adalah teknik yang sistematis untuk menganalisis isi pesan atau sebagai alat untuk mengamati dan menganalisis isi komunikasi terbuka dari pembicara. Selain menggunakan teknik analisis multifaset untuk konten media sosial Jokowi, peneliti juga mengumpulkan sampel untuk memvalidasi data dengan menyebarkan kuesioner online untuk 150 orang di seluruh Indonesia. Informan adalah perwakilan dari media sosial Jokowi pada rentang usia (17-40 tahun), lokasi (Indonesia) dan gabungan (warga negara Indonesia dan warga negara asing). Teknik yang diambil dalam pengambilan sampel adalah purposive. Teknik purposive adalah teknik sampling yang unit sampling-nya dipilih berdasarkan pertimbangan tertentu dengan tujuan mendapatkan unit sampling yang memiliki karakteristik atau kriteria yang diinginkan dalam pengambilan sampel.

\section{Hasil dan Pembahasan}

Upaya branding oleh Indonesia dinilai perlu memiliki konsep branding yang lebih informatif, terutama setelah beberapa tahun terakhir yang tidak konsisten dan pesan yang tidak seragam, yang dibawa oleh Jokowi untuk mendorong branding bangsa. Inisiatif ini didorong lebih lanjut dengan menggunakan platform media sosial untuk mempromosikan Indonesia dan menciptakan diplomasi dengan negara lain.

Selain itu, banyak pengamat branding dan ilmu pemasaran mengakui peran media online dan jaringan sosial sangat besar dalam membangun 'popularitas' merek di masyarakat. Kehadiran Jokowi di media sosial adalah relevan dan praktis untuk keberhasilan strategis secara keseluruhan dari kampanye Wonderful Indonesia. Presiden berfungsi sebagai wajah merek Indonesia, memberikan interaksi langsung dengan khalayak umum pada pesan bermerek, yang juga bermain di media cetak dan media konvensional lainnya. Upaya ini adalah langkah besar dalam sinergi branding Indonesia untuk masa depan.

Berdasarkan data 2017, jumlah pengguna internet di Indonesia telah mencapai 132, 7 juta orang. Orang ini aktif di media sosial, situs web, blog dan platform digital lainnya. Ini menampilkan bahwa Internet berfungsi sebagai saluran untuk mengumpulkan informasi 
apakah hal itu berkaitan dengan kehidupan sosial atau kebijakan publik. Sekitar 6,75\% pengguna Internet Indonesia mengikuti akun Twitter Presiden Jokowi. (Kemp, 2017) Berikut adalah informasi mengenai kinerja akun Twitter @Jokowi jika ditinjau melalui karakter akun dan bagaimana interaksi yang terbentuk antara pemilik akun dan pengikut pada platform tersebut.

Tabel 1. Informasi dan Kinerja Akun Twitter @ Jokowi

\begin{tabular}{l|l}
\hline Variabel & Deskripsi \\
\hline Followers & 8.952 .850 \\
Following & 59 \\
Average Likes & 10,382 \\
Average Retweet & 3,746 \\
Jumlah Post & 788 \\
Estimasi Jangkauan/100 Tweets & 1.009 .368 \\
Perkiraan Tayangan/100 Tweet & 1.174 .029 \\
Demografis: & \\
Pria & $49 \%(4.565 .954)$ \\
Umur Rerata & 22 tahun \\
Kota Terpopuler & Jakarta $(50 \%)$ \\
& Surakarta $(9 \%)$ \\
& Yogyakarta $(8 \%)$ \\
\hline
\end{tabular}

Sumber: Hasil Penelitian

Menurut data pada tabel di atas, jumlah orang yang mengikuti akun twitter presiden adalah 8.952.850. Per 100 tweet dia terlihat (tayangan) 1,174,029 kali. Jika ditinjau dari asumsi data untuk menampilkan dampak digital dari kehadiran Jokowi di Twitter mengenai kapan kampanye pencitraan merek nasional dimulai (27 September 2016 hingga 10 November 2017), kontennya telah dilihat sebanyak 3.522.087 kali. Akun Presiden juga telah mendapatkan 1,009.368 unik orang per 100 tweet. Dengan asumsi pertumbuhan 5\% dalam jangkauan, kampanye branding negara telah mencapai 1.059 .836 orang pada medium twitter saja.

Akun Twitter Presiden dengan username @Jokowi, telah menciptakan 322 tweet dari 27 September 2016 hingga 10 November 2017. Kali ini merupakan bagian dari rapat kabinet yang memulai pelaksanaan kampanye branding negara. Konten pada saluran media sosial dibagi menjadi 6 kategori yang berhubungan dengan dimensi/saluran strategi nation branding Anholt yang berdampak pada reputasi suatu negara.

Konten yang berkaitan dengan pekerjaan kabinet saat ini dan yang sedang berjalan dikategorikan dalam "Tata Kelola Pemerintah/Kebijakan" yang menyumbang mayoritas tweet, yakni sejumlah 124 dari total 322. Urutan kedua dari tweet yang paling sering dituliskan ialah mengenai topik konten "Pribadi" yang tidak terkait dengan pemerintahan, kategori ini menyumbang sebanyak 65 tweet. Diikuti oleh kategori "Ekspor/Hubungan Internasional" yang berjumlah 45 tweets, "Budaya/Warisan Budaya" hadir dengan jumlah 33 
tweets, "Pandangan politik" berjumlah 30 tweets, dan akhirnya "Pariwisata" yang menyumbang 25 tweets. Kategorisasi konten dari tweet dapat dilihat lebih jelas dalam tabel di bawah.

Tabel 2. Kategorisasi Konten di Akun Twitter@ Jokowi Pada 27 September 2016 Hingga November 2017

\begin{tabular}{lcc}
\hline Topik & Jumlah Tweets & Persentase \\
\hline Tata Kelola & 124 & $39 \%$ \\
Pemerintah/Kebijakan & & \\
Budaya/Warisan Budaya & 33 & $10 \%$ \\
Ekspor/Hubungan & 45 & $14 \%$ \\
Internasional & & \\
Pribadi/Masyarakat & 65 & $20 \%$ \\
Pariwisata & 25 & $8 \%$ \\
Pandangan Politik & 30 & $9 \%$ \\
Jumlah & $\mathbf{3 2 2}$ & $\mathbf{1 0 0 \%}$ \\
Sumber: Hasil Penelitian & &
\end{tabular}

Pembahasan tentang penerapan enam dimensi Hexagon Identitas Kompetitif oleh Simon Anholt pada Akun Twitter Jokowi adalah sebagai berikut: (1) Pariwisata: Mempromosikan pariwisata dan pengalaman masyarakat tangan pertama dalam mengunjungi negara sebagai wisatawan atau pelancong bisnis. Jokowi sendiri berbagi pengalamannya saat berjalan melintasi berbagai daerah di Indonesia. Namun, hal ini memang mengundang reaksi beragam dari publik. Konten pariwisata ini disajikan dalam berbagai bentuk oleh Presiden Jokowi, misalnya ketika di zona ekonomi khusus Mandalika, Jokowi menyajikan konten tidak hanya terbatas pada koleksi teks naratif tetapi juga berbagi video blog yang sekarang menjadi konten yang sering digunakan untuk menjangkau pemirsa di generasi muda cenderung lebih menarik dan mengikuti tren saat ini. Dalam kontennya, Jokowi menjadi komunikator utama dalam video tersebut bersama dengan kepala daerah dari masing-masing tempat yang dikunjungi olehnya. Namun konten video dibuat sekreatif dan semenarik mungkin dengan visualisasi yang juga diiringi dengan musik yang enak didengar.

Selanjutnya, Pada kategori Ekspor \& Hubungan Internasional, Jokowi menampilkan konten yang lebih berkaitan dengan proses diplomatik saat mengunjungi atau menerima diplomat negara lain di Indonesia. Selain itu, Jokowi menyebutkan potensi barang lokal yang dapat dikomersialkan di luar negeri, tetapi porsinya masih sedikit dibandingkan dengan kunjungan kerja. Kunjungan kerja yang dimaksud adalah ketika Presiden Jokowi menghadiri KTT Kelompok 20 atau 20 di Hamburg, Jerman, dan kemudian menangkap momen tersebut dengan salah satu kepala negara hadir: Perdana Menteri Kanada Justin Trudeau. Dalam video itu, Presiden Jokowi secara eksplisit mengundang para kepala negara untuk mengunjungi Indonesia. Hal ini merupakan salah satu upaya Presiden Jokowi dalam mempromosikan negara dan juga menjadi salah satu faktor daya tarik bagi negara lain dalam kampanye Wonderful Indonesia. 
Pada kategori "Tata Kelola Pemerintah/Kebijakan" terdapat sejumlah tweet yang menampilkan bagaimana keputusan kebijakan pemerintah atau kemajuan terkait program kerja kabinet pemerintah, yang memiliki porsi terbesar (39\%). Presiden Jokowi, dalam hal ini, menjadi representasi dari kabinet kerja dalam menyebarluaskan program-program yang dilakukan untuk menyukseskan program Nawacita. Itu diilustrasikan melalui konten media sosial Presiden Jokowi yang juga membantu menjelaskan kebijakan spesifik, misalnya ketika kebijakan Pajak Amnesti diterapkan oleh Kementerian Keuangan. Presiden Jokowi juga berperan sebagai influencer yang baik dalam keberhasilan program sehingga berdampak positif juga pada keberhasilan program. Selanjutnya, pada kategori "Budaya dan Warisan Budaya" terdapat tweet yang menampilkan bagaimana Indonesia hadir melalui pertukaran budaya dan kegiatan budaya dan ekspor, diantaranya ialah tur dunia oleh tim olahraga, merekam musisi terkenal, penyair, dan penulis dan pembuat film serta seni, pertandingan sepak bola lokal yang bersaing saat ini. Juga terkait dengan kesenian, acara sepak bola tanah air saat berlaga. Presiden Jokowi bersama-sama menulis tentang keragaman budaya di Indonesia atau berbagi momen terkait dengan budaya lokal ketika ia melakukan kunjungan kerja di negara tersebut.

Jika dibandingkan dengan kategori sebelumnya, terdapat perbedaan dalam kategori "Pribadi / Komunitas", di mana Presiden Jokowi cenderung berbagi kehidupan sehari-hari atau kehidupan sosialnya dengan orang-orang yang tidak ada hubungannya dengan urusan pekerjaan pemerintah. Konten media sosial ini termasuk kategori yang paling diminati oleh pengikut Presiden Jokowi di media sosial karena menunjukkan sisi lain kehidupan seorang presiden, seperti ketika ia berbagi konten dengan keluarga, seperti video blog ketika Presiden Jokowi dengan cucunya atau selama momen pernikahan Kahiyang, putrinya yang baru menikah pada November 2017. Kemudian, pada kategori terakhir yakni "Pandangan Politik", bentuk tweet yang disiarkan lebih berisi mengenai bagaimana Jokowi memberikan pendapatnya tentang sistem demokrasi atau mewakili kepentingan politik tertentu di Indonesia, termasuk saat terlibat dalam kegiatan partai politik yang mencakup dirinya sendiri. Dalam kategori ini, terdapat konten ketika Presiden Jokowi menghadiri acara-acara partai politik seperti PDI-P, atau pada saat pencalonannya dari Partai Nasdem. Konten tersebut juga berisi komentarnya tentang gejolak politik yang terjadi di Indonesia.

Berdasarkan data pada kategori konten di atas, dapat diamati bahwa Presiden Jokowi bukan hanya pemimpin nasional yang secara aktif menggunakan media sosial untuk berkomunikasi dengan masyarakat. Di regional ASEAN misalnya, hampir semua pemimpin nasional memiliki akun di media sosial. Perdana Menteri Singapura Lee Hsien Loong, misalnya, dikenal sebagai pemimpin ASEAN yang aktif dan memahami cara menggunakan media sosial untuk berkomunikasi secara efektif dengan komunitasnya. Dia memiliki akun Twitter dengan 269 ribu pengikut, Instagram dengan 199 ribu pengikut, dan Youtube.

Terdapat pula tweet favorit atau yang memiliki kontribusi terbesar untuk kinerja akun media sosial Jokowi, yang masih didominasi oleh topik pribadi dan komunitas, ini menjadi konten yang paling populer di kalangan pengikutnya. 
Tabel 3. Tweet Teratas Pada Akun Twitter @ Jokowi

\begin{tabular}{l|lll}
\multicolumn{1}{c}{ Topik } & \multicolumn{1}{c}{ Konten } & $\begin{array}{l}\text { Jumlah } \\
\text { Likes }\end{array}$ & $\begin{array}{l}\text { Jumlah } \\
\text { Retweets }\end{array}$ \\
\hline Pribadi/Masyarakat & Pernikahan Kahiyang Ayu & 36.740 & $\mathbf{1 2 . 1 6 2}$ \\
Pribadi/Masyarakat & Vlog- Bermain dengan Cucu & 25.229 & $\mathbf{8 . 5 9 7}$ \\
Pribadi/Masyarakat & Ucapan SelamatUlang Tahun & 25.021 & $\mathbf{9 . 2 1 5}$ \\
$\begin{array}{l}\text { Ekspor/Hubungan } \\
\text { Internasional }\end{array}$ & Pertemuan dengan Obama & 22.470 & $\mathbf{9 . 6 3 0}$ \\
$\begin{array}{l}\text { Pandangan Politik } \\
\text { Budaya/Warisan }\end{array}$ & Pandangan mengenai Komisi & 21.792 & $\mathbf{1 1 . 7 0 5}$ \\
Budaya & Pemberantasan Korupsi (KPK) & & \\
& Tim Nasional dan U-18 AFF $=$ & 20.232 & $\mathbf{9 . 1 1 7}$ \\
& & &
\end{tabular}

Sumber: Hasil Penelitian

Berdasarkan reaksi publik terhadap kehadiran presiden di media sosial, kebanyakan orang lebih tertarik dengan topik-topik pribadi yang lebih ringan. Orang-orang juga lebih cenderung mengkonsumsi konten yang ringan dan menghibur. Contohnya adalah konten termasuk pernikahan anak Jokowi, ucapan selamat ulang tahun, atau video presiden yang diputar bersama cucu-cucunya. Ini menunjukkan bahwa topik kehidupan pribadi lebih diterima dengan baik oleh publik.

Untuk memperkuat kampanye Wonderful Indonesia, topik yang berkaitan dengan keunggulan dan keunikan tujuan wisata di negara ini perlu mendapatkan porsi lebih banyak, karena itu perlu untuk menunjukkan peningkatan kinerja di tiga bidang: aksesibilitas transportasi ke tujuan wisata, keanekaragaman Fasilitas hotel, losmen, restoran, dan fasilitas lainnya), serta atraksi unik yang menarik di tujuan wisata utama. Ketiganya dalam pariwisata disebut 3A. Secara konseptual, Kim, Bach, dan Cleland (2007) menyebut istilah Reputasi Kinerja dan Reputasi Simbolik. Upaya untuk menonjolkan kinerja yang dicapai akan memperkuat kinerja nyata atau Reputasi Kinerja yang berdampak lebih kuat daripada pembombardan iklan pariwisata di media massa, bahkan media sosial karena itu hanya akan meningkatkan Reputasi Simbolik Indonesia dalam perspektif wisatawan.

Meskipun konten yang berkaitan dengan pariwisata tidak termasuk di antara tweet paling populer, topik tersebut memang mengundang reaksi positif dari publik. Hasilnya menunjukkan bahwa 53\% orang telah melihat konten tentang pariwisata yang dibagikan oleh Jokowi, sementara $43 \%$ mengatakan mereka tidak. Hal lain yang menarik adalah, 99\% dari mereka tertarik untuk mengunjungi venue sementara hanya $1 \%$ mengatakan bahwa mereka tidak tertarik ketika datang ke Mandalika, kawan ekonomi khusus. Selain itu, pengemasan dan pengiriman konten Kawasan Ekonomi Khusus dibuat dengan cara yang menarik dengan memanfaatkan blog video, sebuah tren yang digunakan oleh milenium, termasuk metodologi komunikasi yang ringan dan sederhana.

Dalam hal ini, Presiden Jokowi memainkan perannya sebagai pemberi pengaruh bagi Wonderful Indonesia. Contoh lain dari key opinion leader yang baik adalah kolumnis dan selebriti media sosial. Jadi dalam upaya nation branding, Indonesia sangat baik untuk 
mendorong pesan yang ingin disampaikan dari kampanye Wonderful Indonesia melalui perwakilannya di media sosial.

Sehubungan dengan reaksi publik mengenai konten pariwisata, kampanye nation branding juga didukung oleh kampanye Wonderful Indonesia yang hadir di arena branding internasional. Berdasarkan data dari World Economic Forum tentang peringkat country branding, Wonderful Indonesia kini berada di peringkat ke-47. Posisi ini mengalahkan Thailand (Amazing Thailand) di posisi ke-67 dan Malaysia (Truly Asia) di 85. Selain itu, The Telegraph melaporkan bahwa Indonesia telah memasuki 20 besar Destinasi Perjalanan Tumbuh Tercepat. Ini adalah momen yang produktif karena hanya ada dua anggota ASEAN dalam kategori ini, Indonesia dan Vietnam. Kedua negara ini tumbuh lebih dari $20 \%$, sementara Singapura, Malaysia, dan Thailand tumbuh kurang dari 5\%. Prestasi lain dalam lingkup kampanye Wonderful Indonesia juga dibuktikan dalam ajang Kompetisi Video Organisasi Pariwisata Dunia PBB (UNWTO) 2017. Dua kategori yang dimenangkan adalah video pariwisata terbaik di Asia Timur dan Pasifik, dan People Choice Award.

Fakta yang menarik adalah bahwa aksi dan konten yang dimiliki oleh Presiden Jokowi berdampak besar pada jumlah pemilih video Wonderful Indonesia. Suara itu langsung meroket oleh hampir 50.000 pemilih. (Erikania, 2017) Analogi tempat sebagai produk memberikan saingan yang berguna untuk memahami pendekatan merek tempat di mana terdapat perbedaan mendasar dalam menerapkan teori merek di lingkungan tempat. Misalnya, peran organisasi pemerintah, kesulitan membangun entitas branding (kota, wilayah, atau negara), tantangan menyatukan pemangku kepentingan internal (penduduk, pemilik bisnis, pekerja terkemuka), dan kesulitan menjaga konsistensi merek dan sumber daya. menghadapi perusahaan publik. (Yananda, dkk, 2014)

Peningkatan peringkat Indonesia di tingkat internasional adalah tonggak penting Presiden ketika ia memilih untuk memodernisasi dan mendorong pencitraan merek negara dengan kampanye payung terpadu dan pesan inti tunggal untuk diterapkan oleh penduduk dan negara. Dimensi yang digunakan dalam perhitungan di atas adalah referensi yang akan digunakan untuk negara-negara dalam mengembangkan strategi komunikasinya dalam menerapkan branding tempat.

Pembahasan terakhir adalah mengenai implementasi strategi 3C, yaitu Kompetensi, Kontribusi, dan Komunikasi. Dalam kompetensi nasional, Jokowi menunjukkan keunggulan Indonesia melalui promosi keanekaragaman budaya, pluralitas orang, tujuan yang indah dengan kekayaan alamnya, dan yang terpenting adalah kekuatan ekonomi Indonesia. Dari aspek kontribusi, juga terlihat dengan poin ekspor yang mempromosikan promosi produk lokal serta kontribusi Indonesia terhadap misi perdamaian dunia. Dalam komunikasi, aspek yang menjadi perantara bagi semua dengan elemen kompetensi dan kontribusi dan akhirnya menghasilkan reputasi positif.

\section{Simpulan}

Upaya Indonesia dalam Nation Branding dapat lebih dioptimalkan melalui dimensi tambahan, yang terkandung dalam Nation Branding Index oleh Simon Anholt dan Sun. 
Namun, ini menjadi tantangan dan peluang yang harus dikaji lebih lanjut, terutama yang berkaitan dengan Perdagangan, Pariwisata, dan Investasi (Trade, Tourism and Investment).

Kehadiran Presiden Jokowi di media sosial adalah faktor pendukung dalam implementasi dan keberhasilan branding Indonesia, saat ia melayani peran influencer yang kuat dan kredibel yang mewakili negara. Kehadirannya disambut dengan reaksi positif oleh publik dan para pengikutnya dan dia menambahkan nilai signifikan pada kampanye Wonderful Indonesia.

Selain itu, pengembangan konsep komunikasi yang terkait dengan nation branding harus diberikan lebih banyak arahan dan berfungsi sebagai dasar yang kuat untuk pencapaian yang realistis. Studi ini juga menunjukkan bahwa perlunya pengembangan dimensi lain untuk lebih mendorong nation branding Indonesia, sehingga silo yang terlibat tidak saling berjalan satu sama lain tetapi berjalan secara terintegrasi, berkelanjutan, dan komprehensif.

Upaya untuk menonjolkan kinerja nyata peningkatan $3 \mathrm{~A}$ di bidang pariwisata: Aksesibilitas (Transportasi), Amenitas (Fasilitas) dan Atraksi di destinasi wisata belum optimal karena Twitter Jokowi cukup banyak menonjolkan hal-hal ringan, santai dan pribadi atau keluarga (Reputasi Simbolik), daripada aspek yang berhubungan langsung dengan pariwisata (Reputasi Kinerja).

Sementara penerapan konsep 3C dari Anholt menunjukkan bahwa aspek kompetensi (Competition), kontribusi (Contribution), dan komunikasi (Communication) secara aktif terlibat dalam enam dimensi pencitraan merek bangsa yang kemudian menjadikan kehadiran Jokowi di media sosial menjadi kekuatan pendorong bagi strategi dalam mensukseskan kampanye Wonderful Indonesia.

Selain itu, pengembangan konsep komunikasi yang terkait dengan nation branding harus memberikan lebih banyak arahan dan dasar yang kuat untuk pencapaian yang telah ditetapkan agar realistis dan terarah. Studi ini juga menunjukkan bahwa perlunya pengembangan dimensi lain untuk memprakarsai branding bangsa Indonesia. Sehingga seluruh dimensi tidak berdiri sendiri dan berjalan secara terpisah. Maka untuk mewujudkan inisiasi country branding, semua dimensi berjalan secara terintegrasi, berkesinambungan, dan komprehensif.

\section{Referensi}

Al Hafiz, M. P. (2017, Mei 22). Strategi Marketing Kemenpar Antar Indonesia Jadi Unggulan ASEAN. Marketeers - Majalah Bisnis \& Marketing Online Marketeers.Com. https://marketeers.com/strategi-marketing-kemenpar-antarindonesia-jadi-unggulan-asean/

Allan, M., 2004, Why Brand Places?,Opinion, No. 64. http://www.beyondbranding.com/Agenda_MSA_Article_Feb2004.pdf

Anholt, S (2010). "Places: Identity, Image and Reputation”. London: Palgrave Macmillan.

Anholt, S (2011) "Beyond the Nation Brand: The Role of Image and Identity in International Relations," Exchange: The Journal of Public Diplomacy: Vol. 2: Iss. 1, Article 1.

Anholt, S. (2003). Brand New Justice. The Upside of Global Branding. London: ButterworthHeinemann. 
Anholt, S. (2007). Competitive Identity: The New Brand Management for Nations, Cities and Regions. New York: Palgrave Macmillan.

Buarque, D. (2015). One Country, Two Cups-The International Image of Brazil in 1950 and in 2014: A Study of the Reputation and the Identity of Brazil as Projected by the International Media During the Two FIFA World Cups in the Country. International Journal of Communication, 9, 19.

Budd, R., Thorp, R., \& Donohew. L. (1967). Content Analysis of Communications. CollierMac.

Delorie, J., (2004), “Moulding our National Identity”, http://www.msk.co.ke/

Dinnine, K. (2008). Nation Branding: Concepts, Issues, Practise. Oxford. UK: ButterworthHeinemann.

Dzenovska, D. (2005). Remaking the Nation of Latvia: Anthropological Perspectives on Nation Branding. In Place Branding. 1:2, pp. 173-186.

Erikania, J. (2017, September 15). Indonesia Raih Dua Gelar Juara dalam UNWTO Video Competition 2017-National Geographic. https://nationalgeographic.grid.id/read/13308282/indonesia-raih-dua-gelar-juaradalam-unwto-video-competition-2017

Florek dan F. Conejo. (2006). Export Flagships in Branding Small Developing Countries:

The Cases of Costa Rica and Moldova. Place Branding and Public Diplomacy, 3 (1), 53 72. Future Priorities. Marketing Science. 25 (6), pp 740-59.

Ginesta, X., \& Eugenio, J.d.S. (2014). The Use of Football as a Country Branding Strategy. Case Study: Qatar and the Catalan Sports Press. Spanyol: SAGE Publications

Kaplan, A \& Haenlein, M (2010). Users of the world, unite! The challenges and opportunities of Social Media. Business Horizons (2010) 53, 59-68

Kemp, S. (2017, Februari 16). Digital in Southeast Asia in 2017-We Are Social. https://wearesocial.com/special-reports/digital-southeast-asia-2017

Kim, J., Bach, S., Cleland, I.J. (2007). Symbolic or Behavioral Management? Corporate Reputation in High-Emission Industries. Corporate Reputation Review Vol. 10. New York: Palgrave Macmillan.

Kotler, P., \& Gertner, D. (2002). Country as Brand, Product, and Beyond: A Place Marketing and Brand Management Perspective. The Journal of Brand Management, 9, 249-261. https://doi.org/10.1057/palgrave.bm.2540076

Kriyantono, R. 2012. Teknik Praktis Riset Komunikasi. Jakarta: Kencana Prenada Media Group.

Kurniawan, S. (2017, Mei 24). Tantangan Nation Brand Indonesia di Mata Dunia. Marketeers - Majalah Bisnis \& Marketing Online - Marketeers.Com. https://marketeers.com/tantangan-nation-brand-indonesia-di-mata-dunia/

Lumanauw, N. (2017, Februari 3). Jokowi Keluarkan Empat Jurus Dorong Nation Branding Indonesia. beritasatu.com. https://www.beritasatu.com/ekonomi/412588-jokowikeluarkan-empat-jurus-dorong-nation-branding-indonesia

Martin Lister, M., Dovey, J., Giddings, S., Grant, I., \& Kelly, K. New Media: A Critical Introduction (2nd ed). London and New York: Routledge, 2009 
Ostapenko, N. (2010). Nation branding of Russia through the Sochi Olympic Games of 2014. Journal of Management Policy and Practice, 11(4), 60-63.

Papadopoulos, N., \& Heslop, L. (2002). Country equity and country branding: Problems and prospects. Journal of Brand Management, 9(4), 294-314. https://doi.org/10.1057/palgrave.bm.2540079

Patton, M. (2002). Qualitative Research \& Evaluation Methods. London: Sage Publications

Seo, H. (2013). Online Social Relations and Country Reputation. International Journal Of Communication, 7, 18. Retrieved from https://ijoc.org/index.php/ijoc/article/view/1926

Setkab, H. (2016, September 29). Bukan Sekedar Slogan, Presiden Jokowi: Segera Ambil Langkah Konkret Perkuat Citra Indonesia. Sekretariat Kabinet Republik Indonesia. https://setkab.go.id/bukan-sekedar-slogan-presiden-jokowi-segera-ambil-langkahkonkret-perkuat-citra-indonesia/

Sun, Q. (2009). An Analytical Model of The Determinants and Outcomes of Nation Branding. Dissertation for Degree of Doctor of Philosophy, University of North Texas.

World Tourism Organization, U. N. (2002). The World Ecotourism Summit Final Report (world). https://www.e-unwto.org/doi/pdf/10.18111/9789284405503

Yananda, M.R., dkk (2014). Branding Tempat: Membangun Kota, Kabupaten dan Provinsi Berbasis Identitas. Jakarta: Makna Informasi 